\title{
Evaluation of attitudes of health care professionals towards the use of corticosteroids in the Republic of Kosovo
}

\author{
Emir Behluli $^{1 *}$, Marija Nikoloski ${ }^{3}$, Lidvana Spahiu $^{2}$, Marija Glavas Dodov $^{3}$ \\ ${ }^{1}$ University Clinical Center of Kosovo, Pediatric Clinic, 10000 Pristina, Kosovo \\ ${ }^{2}$ University Clinical Center of Kosovo, Pediatric Clinic, Department of Nephrology, \\ 10000 Pristina, Kosovo \\ ${ }^{3}$ Institute of Pharmaceutical Technology, Faculty of Pharmacy, \\ Ss. Cyril and Methodius University, Majka Tereza 47, 1000 Skopje, Macedonia
}

Received: November 2017; Accepted: February 2018

\begin{abstract}
Irrational use of drugs/medicinal productsremains a major issue facing most health systems across the world, especially the developing countries with weak health systems, where mechanisms for routine monitoring of drug productuse are often not well developed or are at times non-existent. In order to collect preliminary data on real-life attitudes, beliefs and perceptions about the treatment with corticosteroid drugs (CSs), a representative sample of 30caregivers (medical doctors from different specialty) from Republic of Kosovo, was assessed during the period of March to April in 2017, where most of the surveyed (93.30\%) were of Albanian nationality.

More than $86 \%$ of all surveyed respondents confirmed that they prescribed CSs in the last year. According to the answers of the questionnaire, $33.33 \%$ of respondents prescribed 1 to 5 CSs in the last month, $23.33 \%$ of respondents prescribed5 to $10 \mathrm{CSs}$ and $26.67 \%$ more than $15 \mathrm{CSs}$, while $16.67 \%$ not even once. The question concerning the attitudes on CSs treatment was answered as follows: $16.67 \%$ of all respondents had negative attitude on CSs treatment, $60 \%$ of the respondents expressed the opposite opinion, and the other $23.33 \%$ of respondents could not give a definite answer. Data from the separate analyses performed to determine the most common indication showed that allergy was the indication the CSs were mostly prescribed for (70\%). Of the total CSs prescribed, obtained results revealed that low potency CSs (methylprednisolone, hydrocortisone, prednisolone) were often prescribed (70\%), while the most commonly prescribed dosage forms were topical steroids, followed by the inhalation formulations and oral dosage forms ( $33.33 \%)$.
\end{abstract}

Keywords: corticosteroids, irrational use, prescription, survey, corticophobia

\section{Introduction}

According to World Health Organization (WHO) estimation, more than half of all medicinal products (drugs) are inappropriately prescribed, distributed and sold, and more than half of all patients use the prescribed medicines incorrectly. As more than $40 \%$ of hospital costs are pharmaceutical costs, this implies a significant waste of health resources in the world. Inappropriate drug prescription and usage might lead to delay in correct diagnosis and treatment, drug resistance, increase in drug interactions and adverse events. Rational prescription and use of medicines are influenced by different factors such as lifestyles and habits, the culture of medicine use, the

\footnotetext{
*ebehluli_19@hotmail.com
} 
knowledge and culture of healthcare professionals and regulatory organizations' supervision and policies. In a study performed in a number of low- and middle-income countries, the reasons for physicians' irrational drug prescription were as follows: lack of written and effective guidelines, lack of effective inspection and supervision and lack of clear policy (Yousefi et al., 2012).

Corticosteroids (CSs) are today among the most widely used drugs in the world as a therapeutic group for the relief of symptoms in many inflammatory and immune diseases. Irrational prescription and overuse of CSs have been reported during recent years, as a result of lack of knowledge, poor availability of proper alternative medicines and weak supervision of regulatory bodies (Bahmani et al., 2016). In spite of this, concerns regarding CSs use, broadly known as corticophobia, are highly prevalent among patients and often result in nonadherence to CSs, which leads to poor disease control and increased health care costs (Mueller et al., 2016).

CSs are the most commonly prescribed medications in clinical practice due to their wide indications and high potency. The clinical effects are mediated by their antiinflammatory, vasoconstrictive, antiproliferative, and immunosuppressive properties. They are prescribed and used in treatment of various chronic inflammatory and autoimune disease conditions such as: asthma, skin diseases, and rheumatoid arthritis. Steroid therapy is always associated with multiple drug interactions, adverse effects and super infections. With the increasing number and types of CSs available to clinicians, there is a need to better understand current prescribing practices (Chaudhari et al., 2015). Prolonged use of CSs is associated with a wide range of adverse effects like: adrenal suppression, effect on bone metabolism, growth suppression in children, impaired skin collagen synthesis, cataract, metabolic disturbances, as well as effect on central nervous system (Kuna et al., 1998).

In several studies it is observed that there is considerable misuse of CSs in non-indicated conditions such as: cough and obstructive lung disease, melasma, urticaria, and even undiagnosed skin rash (Chaudhari et al., 2015; Rathi et al., 2012). Owing to such a rampant practice, it is imperative to monitor the rational use of this class of drugs. A proper intermittent and judicious monitoring is a prime requisite to minimize irrational practice of drug prescription, to analyze the rationality of every prescription, to offer suitable modifications in prescribing pattern to increase the therapeutic benefits and reduce adverse effects (Mukherjee et al., 2016).

The aim of the present study was to assess health care workers' attitudes, perceptions, beliefs and practice in prescription of the CSs in Republic of Kosovo (RKS), as well as to to monitor the utilization pattern of CSs intermittently and to analyze the rationality of drug usage.

\section{Material and methods}

\section{Study design and population}

In order to collect preliminary data on real-life attitudes, beliefs and perceptions about the treatment with CSs, a study consisted of a survey structured as a questionnaire was performed and a target group of family physicians, specialists in internal medicine, pediatricians, specialists in dermato-venereology, specialists in allergy and immunology and physicians from other specialties was assessed.

Also, the screening questionnaire was developed with the aim to explore the level of understanding, acceptability (questions wording, complexity and ambiguity of proposed answers) as well as the time required to complete the questionnaire. Among all physicians in RKS, estimated to be 1068 in 2015, we selected a random sample of 30 . The study was performed in Prishtina and the responses were collected face-to-face in physicians`offices from March to April 2017.

\section{Questionnaire development}

The questionnaire was consisted of 37 questions, where combined open ended and multiple-choice closed questions were used, related to: socio-demographic factors (age, nationality, gender, working experience), location, workplace and average number of patients in the last three months; type, dosage and pharmaceutical form of used CSs; attitudes (satisfaction, importance of corticosteroids recommendations) and every day practice in selection of the first line therapy.

\section{Statistical analysis}

Obtained data were tabulated using Microsoft Excel (Microsoft Corp. Redmond, WA, USA), computed and consequently evaluated using statistical software STATGRAPHICS Centurion XVI evaluation (Stat Point technologies Inc., USA).

\section{Results and discussion}

This study included a representative sample of 30 physicians with average age $( \pm \mathrm{SD})$ of $47.8 \pm 9.5 \mathrm{yrs}$, where male and female gender was equally represented. Most of the surveyed medical doctors (93.3\%) were of Albanian nationality, while the rest belonged to the Bosnian (3.3\%) and Turkish (3.3\%) ethnic groups. The majority $(60 \%)$ worked in a public sector, and the others in both (public and private). $40 \%$ of the health professionals worked in a community health 


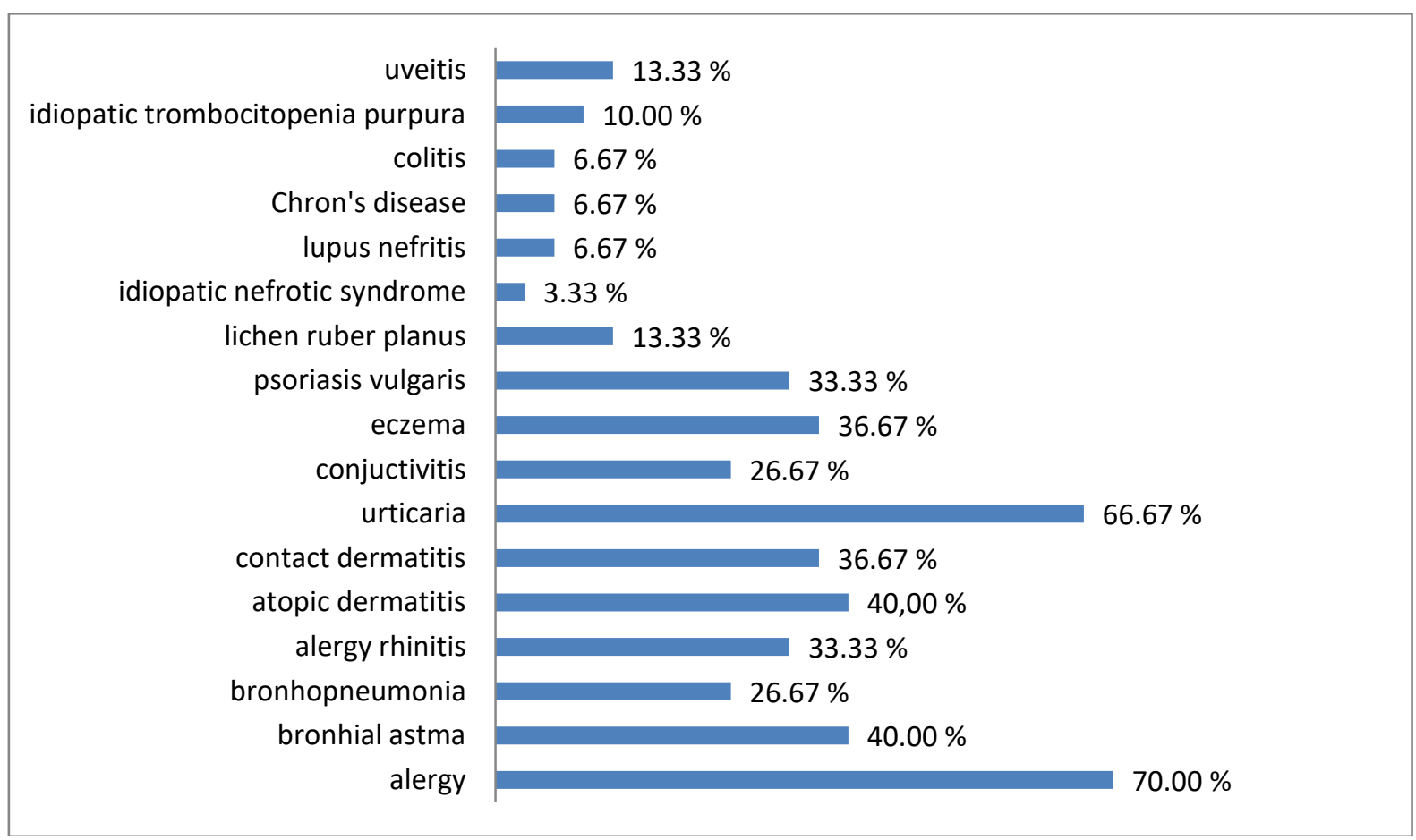

Fig. 1. Most common conditions treated with CSs.

center,33.33\% worked in a hospital and $26.67 \%$ in a university clinical center, with average work experience of $16.8 \pm 9.8 \mathrm{yrs}$. In the last three months the number of patients per doctor was in a range from 16 to 2700 .

More than $86 \%$ of all surveyed respondents confirmed that they prescribed CSs in the last year, when $57.70 \%$ recommended the use of CSs up to one week. These results were in a correlation with the data obtained in a survey held in Republic of Macedonia (RM) where it was revealed that $54.49 \%$ of respondents used topical CSs up to one week. $21.6 \%$ of them up to two weeks, while the duration of treatment was not defined only by $5.98 \%$ (Glavas Dodov et al., 2016). Apart from the potency and regimens, authorities are agreed that CSs should be prescribed at the lowest effective dose for the shortest possible time (Cave et al., 1999). Respondents were also asked for how often they prescribe CSs. Obtained answers concerning the number of prescribed CSs per month pointed that $33.33 \%$ of respondents prescribed 1 to $5 \mathrm{CSs}$ in the last month, $23.33 \%-5$ to $10 \mathrm{CSs}$ and $26.67 \%$ more than $15 \mathrm{CSs}$, while $16.67 \%$ not even once.

The survey showed that $60 \%$ of interviewed respondents agreed that the treatment with CSs was successful. However, the fact that more than a half of the surveyed doctors prescribed CSs with a concern $(56.70 \%)$ is worth to notice. These results were in accordance with the previous findings where $\sim 40 \%$ of medical doctors in RM were concerned about use of CSs for topical treatments (Glavas Dodov et al., 2016).

Regarding data on the attitudes on CSs treatment,
$16.67 \%$ of all respondents had negative attitude on CSs treatment, $60 \%$ of the respondents expressed the opposite opinion, and the other $23.33 \%$ of respondents could not give a definite answer. This is in accordance with the results presented in a research paper on the assessment of the attitudes towards the use of topical CSs in the RM, where $74.75 \%$ of all respondents had positive attitude on the treatment with topical CSs (Glavas Dodov et al., 2016). The results were supported by the fact that most of the medical doctors believed that CSs treatment was successful only if it was of short duration. Obtained results were in accordance with answers to the previous question, where medical doctors expressed their positive attitudes for CSs treatment. These results were supported by the fact that most of them $(42.50 \%)$ had the positive point of view from personal experience and $17.50 \%$ from colleagues, and only $10 \%$ from clinical researchers.

CSs were mostly prescribed in allergies $(70 \%)$ and the other conditions are presented in Fig. 1. In a population cohort study held in the United States it was identified that the most common indications for short term oral corticosteroid use were upper respiratory tract infections, spinal conditions and intervertebral disc disorders, allergies, bronchitis, and (non-bronchitic) lower respiratory tract disorders (Waljee et al., 2017). This data is in accordance with the results obtained from a research in the United Kingdom, where also the respiratory system (39.90\%) and the Chronic obstructive pulmonary disease $(30.50 \%)$ were the most frequent CSs treated conditions (Staa et al., 2000). A study of prescribing pattern of 
topical CSs in dermatology in India revealed that commonly encountered skin conditions were eczema $(13 \%)$, Psoriasis vulgaris $(12 \%)$ and Lichen simplex chronicus (11.05\%) (Manju et al., 2018).

Low potency CSs (methylprednisolone, hydrocortisone, prednisolone) were most often prescribed (70\%). Data from a survey on the physicians' perception towards CSs as therapeutic agent suggested that physicians and general practitioners prefer prednisolone as a first drug of choice in respiratory disorders (Chaudari et al., 2015), while the topical CSs that were most commonly prescribed were high potency drugs such as: clobetasol propionate $(34.50 \%)$, mometasone furoate (24\%), betamethasone dipropionate $(18 \%)$ and halobetasol $(11 \%)$ (Manju et al., 2018). The question concerning most frequently prescribed topical CSs in RM was answered as follows: betamethasone dipropionate (38.94\%), diflucortolone valerate $(30.10 \%)$ and the combination of betamethasone dipropionate and salicylic acid (18.77\%) (Glavas Dodov et al., 2016).

Nearly $57 \%$ of the surveyed medical doctors answered that the most commonly prescribed dosage forms were topical steroids (for skin, mucus and eyes), $33.33 \%$ either as inhalation and oral formulation, and around $30 \%$ for parenteral administration.

In the present study, only $26.67 \%$ of the total survey respondents noticed some side effects where the skin redness was the most frequently observed side-effect for topical dosage forms. This fact is supported with the information obtained from a clinical study in India, revealing that acne $(37.99 \%)$ and plethoric, puffy face with telangiectasia (18.99\%) were the most common adverse effects noted (Kumar, 2014).

More than a half $(56.67 \%)$ of all surveyed respondents answered that the price and the brand of the CSs are very important in their daily prescribing which is in accordance with the latest research data.

\section{Conclusion}

Tackling the issue of irrational medicine use is a major global health challenge and is considered to be essential not only to improve healthcare delivery towards ensuring patient safety, but also to allow optimal utilization of resources. CSs may be a valuable therapeutic option for many diseases, but the benefits and burdens must be carefully examined. The results of the performed study provide a clear picture of the prescribing pattern of CSs in RKS with an aim to find effective factors in irrational prescription of CSs and design suitable interventions to decrease prescription rates of CSs.

\section{References}

Bahmani, R., Moghaddam, G., Noubarani, M., 2016. Prescription pattern of croticosteroids in zanjan Iran. Iranian J. Pharm. Sci. 12(4), 63-68. Available at: https://doi.org/10.22034/IJPS.2016.25448.

Cave, A., Arlett, P., Lee, E., 1999. Inhaled and nasal corticosteroids: factors affecting the risks of systemic adverse effects. Pharmacol. Ther. 83(3), 153-179. Available at: Available at: https://doi.org/10.1016/s01637258(99)00019-4.

Chaudhari, E.H., Panchmiya, H.R., Goyal, S.N., Patil, C.R., 2015. Physicians Perception towards Corticosteroids as Therapeutic Agent: A Survey. Journal of Pharmaceutical Research \& Clinical Practice 5(1), 1-12.

Glavas Dodov, M., Simonoska Crcarevska, M., Sulevski, V., Slaveska Raicki, R., Starova, A., 2016. Assessment of attitudes towards the use of topical corticosteroids among patients, prescribers and pharmacists in the Republic of Macedonia. Maced. Pharm. Bull. 62(1), 25-34.

Kumar, D.V., 2014. Misuse of topical corticosteroids: A clinical study of adverse effects. Indian Dermatol. Online J. 5(4), 436-440. Available at: https://doi.org/10.4103/22295178.142486 .

Kuna, P., 1998. Long term effects of steroid therapy. Wiad. Lek. 51(Suppl 1), 12-18.

Manju, K., Saravanan, R., Balan, S., Menon, R., David, G.B., 2018. Study of prescribing pattern of topical corticosteroids in dermatology out patients' department in a Tertiary Care Hospital in Puducherry. International Journal of Pharmacological Research 8(1), 1-5. Available at: https://doi.org/10.7439/ijpr.v8i1.4576.

Mueller, M.S., Itin, P., Vogt, R.D., Walter, M., Lang, U., Griffin, L.L., Euler, S., 2016. Assessment of "corticophobia" as an indicator of non-adherence to topical corticosteroids: A pilot study. J. Dermatolog. Treat. 28(2), 104-111. Available at: https://doi.org/10.1080/09546634.2016.1201189.

Mukherjee, S., Era, N., Banerjee, G., Tripathi, S.N., 2016. Assessment of corticosteroid utilization pattern among dermatology: outpatients in a tertiary care teaching hospital in Eastern India. International Journal of Green Pharmacy 10(4), S182.

Rathi, S.K., D’Souza, P, 2012. Rational and ethical use of topical corticosteroids based on safety and efficacy. Indian J. Dermatol. 57(4), 251-259. Available at: https://doi.org/10.4103/0019-5154.97655.

Staa, T.P., Leufkens, H.G.M., Abenhaim, L., Begaud, B., Zhang, B., Cooper, C., 2000. Use of oral corticosteroids in the United Kingdom. QJM: An International Journal of Medicine 93 (2), 105-111. Available at: https://doi.org/10.1093/qjmed/93.2.105.

Waljee, A.K., Rogers, M.A., Lin, P., Singal, A.G., Stein, J.D., Marks, M.R., Ayanian, Z.J., Nallamothu, B.K., 2017. Short term use of oral corticosteroids and related harms among adults in the United States: population-based cohort study. BMJ 357, j1415. Available at: 
https://doi.org/10.1136/bmj.j1415.

Yousefi, N., Majdzadeh, R., Valadkhani, M., Nedjat, S.,

Mohammadi, H, 2012. Reasons for physicians' tendency to irrational prescription of corticosteroids. Iran Red. Crescent. Med. J. 14(11), 713-718. Available at: https://doi.org/10.5812/ircmj.2284.

\title{
Резиме
}

\section{Евалуација на ставовите на здравствените работници за употребата на кортикостероиди во Република Косово}

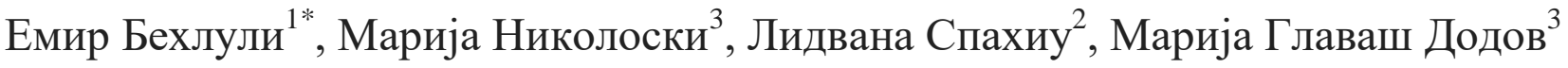 \\ ${ }^{1}$ Универзитетски клинички иุентар на Р. Косово, Детска клиника, 10000 Приштина, \\ Р. Косово \\ ${ }^{2}$ Универзитетски клинички иентар на Р. Косово, Детска клиника, \\ Институт за нефрологија, 10000 Приштина, Р. Косово \\ ${ }^{3}$ Институт за фармацевтска технологија, Фармацевтски факултет, \\ Универзитет „Св. Кирил и Методиј”, Мајка Тереза 47, 1000 Скопје, Р. Македонија
}

Клучни зборови: кортикостероиди, нерационална употреба, пропишување, анкета, кортикофобија

Нерационалната употреба на лекови/лековити производи претставува голем проблем со кој се соочуваат повеќето здравствени системи низ светот, особено земјите во развој со слаби здравствени системи, каде што механизмите за рутински мониторинг на употребата на лекови честопати не се добро развиени или пак воопшто не постојат. Со цел да се добијат прелиминарни податоци за реалните ставови, верувања и перцепции во врска со третманот со кортикостероидните лекови (КС), во периодот од март до април, 2017 година, биле собирани одговори од репрезентативен примерок од 30 испитаници (лекари од различна специјалност) од Република Косово. Најголем дел од анкетираните (93,30\%) биле од албанска националност.

Повеќе од 86\% од сите анкетираните испитаници потврдиле дека пропишале КС во последната година. Според одговорите на прашалникот, 33,33\% од испитаниците во последниот месец пропишале 1 до 5 КС, 23,33\% од испитаниците пропишале од 5 до 10 КС, 26,67\% пропишале повеќе од 15 КС, додека пак 16,67\% не пропишале КС ниту еднаш. На прашањето поврзано со ставовите за третман со КС, 16,67\% од испитаниците имале негативен став во однос на третманот со КС, $60 \%$ од испитаниците го искажале спротивното мислење, а останатите $23,33 \%$ од испитаниците не можеле да дадат дефинитивен одговор. Податоците од посебните анализи направени со цел да се утврди најчестата индикација за третман со КС, покажале дека алергијата е состојбата за која се најчесто се пропишуваат КС (70\%). Истотака, добиените резултати покажале дека најчесто пропишувани се ниско потентните КС (метилпреднизолон, хидрокортизон, преднизолон) (70\%), додека пак најчесто пропишувани дозирани форми претставуваат топикалнит еКС, како и инхалационите и пероралните фармацевтски дозирани форми (33,33\%). 
